\title{
BIOREMEDIASI LINGKUNGAN TERCEMAR KLORPIRIFOS
}

\author{
Candra Dwi Anggreini \\ Jurusan Teknik Lingkungan, Fakultas Arsitektur Lanskap dan Teknologi Lingkungan, \\ Universitas Trisakti, Jakarta, Indonesia
}

Email korespondensi: candra08215015@ std.trisakti.ac.id

\begin{abstract}
ABSTRAK
Insektisida merupakan bagian yang tidak dapat dipisahkan dari sektor pertanian karena dapat membasmi serangga yang dapat menurunkan produktivitas hasil pertanian. Salah satu jenis insektisida yang sering digunakan adalah klorpirifos, yaitu insektisida organofosfat dengan rumus molekul $\mathrm{C}_{9} \mathrm{H}_{11} \mathrm{Cl}_{3} \mathrm{NO}_{3} \mathrm{PS}$. Meluasnya penggunaan klorpirifos ini berbahaya bagi lingkungan karena dapat mencemari tanah pertanian, air tanah, bahkan badan air dan juga beracun bagi mamalia, oleh karena itu penting untuk menghilangkannya dari lingkungan. Beberapa metode untuk menanggulangi residu klorpirifos di lingkungan telah dilakukan, yaitu menggunakan metode fisika kimia. Namun, metode ini kurang efektif karena memerlukan biaya besar dan memungkinkan timbulnya pencemar sekunder. Karena metode fisika kimia kurang efektif, maka alternatif lain adalah dengan menggunakan pendekatan secara biologi, salah satunya adalah bioremediasi. Bioremediasi menjadi alternatif pilihan untuk menanggulangi residu klorpirifos di lingkungan karena memanfaatkan aktivitas enzimatis mikroba seperti bakteri, fungi, dan alga untuk mendegradasi klorpirifos, sehingga bersifat ramah lingkungan dan tidak menimbulkan pencemaran sekunder. Dalam karya tulis ilmiah ini mencoba menyajikan informasi mengenai keunggulan bioremediasi dan potensi beberapa jenis mikroba dalam mendegradasi klorpirifos di lingkungan. Dengan demikian, tujuan dari karya tulis ilmiah ini adalah untuk memberikan informasi mengenai teknologi bioremediasi untuk menyisihkan klorpirifos dari lingkungan.
\end{abstract}

\section{Kata Kunci: klorpirifos; bioremediasi; biodegradasi}

\section{PENDAHULUAN}

Penggunaan pestisida secara ekstensif melalui aplikasi di lapangan, penggilingan tanaman, penanganan, pembilasan kontainer, tumpahan tak disengaja, dll memiliki potensi untuk mencemari tanah dengan parah (Briceno G. et al., 2012). Sebagian besar pestisida yang digunakan secara umum saat ini dikenal dapat merusak keragaman fungsional mikrobiota tanah yang menyebabkan hilangnya kesuburan tanah dan terhambatnya pertumbuhan tanaman, sehingga menyebabkan kelestarian tanah pertanian pada risiko serius. Hal ini terjadi karena adanya kandungan insektisida yang kuat (Fang et al., 2009). Menurut Lu et al (2013), untuk menambah kompleksitas situasi, residu pestisida dan metabolitnya sering menyusup melalui permukaan tanah ke dalam air tanah dan menyebabkan kontaminasi luas pada ekosistem air. Selain itu, adanya pencemaran ini menyebabkan tanah pertanian kehilangan kesuburannya karena tidak stabilnya nilai $\mathrm{pH}$ yang merupakan parameter untuk memperkirakan mobilitas unsur-unsur kimia dalam tanah, sehingga $\mathrm{pH}$ dapat dipergunakan untuk mengukur ketersediaan nutrien dan logam berat berkaitan dengan tingkat toksisitas dan pencemaran tanah. Hilangnya kesuburan tanah juga dapat diakibatkan karena miskinnya unsur hara, akumulasi unsur yang bersifat racun, dan aktivitas organisme yang rendah (Chalim, 2010; Widyatmoko 2011).

Klopirifos adalah salah satu insektisida organofosfat dengan spektrum luas yang paling banyak digunakan pada sektor pertanian. Klorpirifos dengan rumus molekul $\mathrm{C}_{9} \mathrm{H}_{11} \mathrm{Cl}_{3} \mathrm{NO}_{3} \mathrm{PS}$ digunakan di seluruh dunia untuk mengendalikan berbagai hama pengunyah dan penghisap, tungau serangga pada berbagai tanaman penting seperti buah jeruk, pisang, sayuran, kentang, kopi, coklat, teh, kapas, gandum, beras, dan sebagainya (Chen et al., 2012). Meskipun klorpirifos dianggap hanya beracun secara moderat, klorpirifos diketahui memiliki sifat neurotoksik dan imunotoksik, dan telah terbukti dapat menjadi berbahaya bagi hewan dan manusia. Klorpirifos juga telah dilaporkan menyebabkan berkurangnya populasi bakteri, jamur, dan diketahui menghambat mineralisasi nitrogen dalam tanah. Pendeteksian kontaminasi klorpirifos pada badan air permukaan dan sedimen yang terkait telah meningkatkan perhatian publik dan membutuhkan perhatian segera untuk masalah tersebut (Akbar et al., 2016). 
Salah satu teknologi yang dapat diterapkan untuk memulihkan lingkungan tercemar klorpirifos adalah bioremediasi. Bioremediasi merupakan penggunaan mikroorganisme untuk membersihkan polusi kimia dengan mengurangi konsentrasi dan/atau toksisitas senyawa kimia dan memulihkan kondisi alam yang bersifat ramah lingkungan karena menggunakan aktivitas enzimatis mikroorganisme dengan memanfaatkan pencemar sebagai sumber nutrisinya (Hardiani et al., 2011). Mikroorganisme yang biasa digunakan dalam bioremediasi tanah tercemar adalah bakteri, fungi, dan alga.

Dari penjabaran di atas, maka di dalam karya tulis menyajikan informasi mengenai keunggulan bioremediasi dalam menyisihkan klorpirifos dan beberapa potensi mikroba dalam melakukan biodegradasi klorpirifos di lingkungan.

\section{TINJAUAN PUSTAKA \\ Bioremediasi}

Bioremediasi adalah proses penguraian limbah organik/anorganik polutan dari sampah organik dengan menggunakan organisme (bakteri, fungi, tanaman atau enzimnya) dalam mengendalikan pencemaran pada kondisi terkontrol menjadi suatu bahan yang tidak berbahaya atau konsentrasinya di bawah batas yang ditentukan oleh lembaga berwenang dengan tujuan mengontrol atau mereduksi bahan pencemar dari lingkungan (Vidali et al., 2011; Singh et al., 2011).

Bioremediasi merupakan pengembangan dari bidang bioteknologi lingkungan dengan memanfaatkan proses biologi dalam mengendalikan pencemaran. Selain biayanya murah, dapat juga dilakukan secara in-situ langsung di tempat dan prosesnya alamiah (Hardiani et al. 2011). Teknologi bioremediasi ada dua jenis, yaitu ex-situ dan in-situ. Ex-situ adalah pengelolaan yang meliputi pemindahan secara fisik bahan-bahan yang terkontaminasi ke suatu lokasi untuk penanganan lebih lanjut. Penggunaan bioreaktor, pengolahan lahan (landfarming), pengomposan adalah contoh dari teknologi ex-situ, sedangkan teknologi in-situ adalah perlakuan yang langsung diterapkan pada bahan-bahan kontaminan di lokasi tercemar (Vidali et al., 2011).

\section{Biodegradasi}

Penggunaan mikroba untuk detoksifikasi, degradasi, dan penghilangan senyawa beracun dari tanah dan air yang terkontaminasi telah muncul sebagai teknik yang efisien untuk membersihkan lingkungan yang tercemar. Degradasi mikroba dari senyawa kimia di lingkungan merupakan rute penting untuk menghilangkan senyawa ini. Biodegradasi senyawa-senyawa ini, misalnya insektisida seringkali berbentuk kompleks dan melibatkan serangkaian reaksi biokimiawi. Saat ini, di antara berbagai kelompok insektisida yang digunakan di seluruh dunia, insektisida organofosfat paling banyak digunakan yang menyumbang lebih dari $36 \%$ dari total pasar dunia. Akumulasi organofosfat ini memilik bahaya kesehatan yang tinggi. Oleh karena itu, degradasi pestisida golongan ini sangat penting dilakukan (Thabit dan Naggar., 2013).

Biodegradasi adalah pendekatan yang andal untuk secara efisien menghilangkan polutan persisten seperti klopririfos. Meskipun banyak bakteri atau jamur yang diisolasi dari lingkungan yang terkontaminasi dan mampu menurunkan klorpirifos, enzim yang bertanggung jawab atas degradasinya masih terbatas untuk diidentifikasi, apalagi mekanisme katalitik enzim (Fan et al., 2017).

Degradasi klorpirifos abiotik, seperti perlakuan kimia, fotodekomposisi, volatilisasi, dan pembakaran, selalu tidak efisien, mahal, dan berbahaya bagi lingkungan, sehingga biodegradasi oleh enzim utama mikroorganisme dianggap sebagai pendekatan yang andal untuk menghilangkan klorpirifos secara efektif dan lengkap (Barman et al., 2014).

\section{Mikroba Pendegradasi Klorpirifos}

Seperti yang diketahui bahwa pertanian intensif sangat tergantung pada penggunaan insektisida kimia untuk mengendalikan serangga. Namun, metode ini memakan waktu dan berbahaya bagi lingkungan. Sebagai bahan kimia yang menumpuk di tanah, mereka menjadi racun bagi mikroorganisme dan tanaman, oleh karena itu, pembersihan tanah menggunakan 
remediasi adalah yang paling penting (Das et al., 2014). Di antara berbagai teknologi remediasi, metode biologis sangat menjanjikan karena mudah dioperasikan, tidak menghasilkan polusi sekunder, dan menunjukkan efisiensi yang lebih tinggi dalam membersihkan tanah. Penggunaan mikroba untuk menghilangkan/degradasi insektisida seperti klorpirifos dari tanah pertanian dikenal luas, sebagian besar melalui degradasi enzimatik (Vladimir P. et al., 2012).

Secara umum, mikroorganisme mampu menekan hama dengan memproduksi racun, menyebabkan penyakit atau mencegah pembentukan organisme lain. Mikroba tanah seperti jamur, bakteri, aktinomisetes, dan protozoa merupakan komponen yang sangat penting dalam ekosistem tanah karena mikroba tersebut memiliki peran utama dalam siklus nutrisi, mempertahankan struktur tanah, dan juga mengatur pertumbuhan tanaman melalui berbagai mekanisme (Vladimir P. et al., 2011).

Mikroba adalah agen biologis utama yang mampu menghilangkan limbah dan bahan-bahan yang merusak, termasuk pestisida, serta mempromosikan daur ulang mereka di lingkungan. Hingga saat ini, penelitian mengenai potensi mikroba sebagai bioremedian telah banyak dilakukan, contohnya adalah eksplorasi potensi kemampuan beberapa jenis bakteri dalam mendegradasi pestisida, salah satunya klorpirifos seperti yang dikemukakan oleh Agustiyani (2011) yang menyatakan bahwa potensi bakteri denitrifikasi dapat dikembangkan sebagai agen dalam bioremediasi pestisida apabila bakteri tersebut mampu memanfaatkan senyawa kompleks pestisida sebagai sumber karbon bagi pertumbuhannya. Beberapa mikroba pendegradasi klorpirifos dapat dilihat pada Tabel 1 dan hasil penelitian terdahulu mengenai beberapa biodegradasi klorpirifos oleh jenis mikroba yang berbeda disajikan pada Tabel 2.

Tabel 1. Mikroba Pendegradasi Klorpirifos

\begin{tabular}{|c|c|c|}
\hline Mikroba & Jenis & Model Degradasi \\
\hline \multirow{4}{*}{ Bakteri } & Eterobacter $\mathrm{sp}$. & Catabolic $(\mathrm{C}, \mathrm{P})$ \\
\hline & Flavobacterium sp. & Co-metabolic \\
\hline & Pseudomanas diminuta & Co-metabolic \\
\hline & Micrococus sp. & Co-metabolic \\
\hline \multirow{4}{*}{ Fungi } & Phanerochaete chrysosporium & Catabolic (C) \\
\hline & Aspergillus $\mathrm{sp}$. & Catabolic (P) \\
\hline & Trickoderma harzianum & Catabolic $(\mathrm{P})$ \\
\hline & Penicilum brevicompactum & Catabolic (P) \\
\hline
\end{tabular}

(Singh et al., 2011)

Tabel 2. Hasil Penelitian Terdahulu

\begin{tabular}{|c|c|c|}
\hline Judul Paper, tahun & Penulis & Hasil Penelitian \\
\hline $\begin{array}{l}\text { Biodegradation of Chlorpyrifos } \\
\text { and Its Hydrolysis Product 3,5,6- } \\
\text { Trichloro-2-Pyridinol by a New } \\
\text { Fungal Strain Cladosporium } \\
\text { cladosporioides Hu-01, } 2012\end{array}$ & $\begin{array}{l}\text { Shaohua Chen, Chenglan Liu, } \\
\text { Chuyan Peng, Hongmei Liu, } \\
\text { Meiying Hu, Guohua Zhong }\end{array}$ & $\begin{array}{l}\text { - Kultur fungi Cladosporium } \\
\text { cladosporioides mampu mendegradasi } \\
50 \mathrm{mg} / \mathrm{l} \text { klorpirifos dalam waktu } 5 \text { hari. } \\
\text { - Kondisi degradasi klorpirifos optimum } \\
\text { terjadi pada suhu } 26,8^{\circ} \mathrm{C} \text { dan pH } 6,5 \text {. }\end{array}$ \\
\hline $\begin{array}{l}\text { Soil bacteria showing a potential } \\
\text { of chlorpyrifos degradation and } \\
\text { plant growth enhancement, } 2016\end{array}$ & $\begin{array}{l}\text { Shamsa Akbar, Sikander } \\
\text { Sultan }\end{array}$ & $\begin{array}{l}\text { Bakteri A. xylosoxidans dan } \\
\text { Ochrobacterium sp. masing-masing } \\
\text { mampu menurunkan } 84,4 \% \text { dan } 78,6 \% \\
\text { dari konsentrasi awal klorpirifos sebesar } \\
100 \mathrm{mg} / \mathrm{l} \text { dalam waktu } 10 \text { hari. }\end{array}$ \\
\hline $\begin{array}{l}\text { Degradation of Chlorpyrifos by } \\
\text { an alkaline phosphatase from the } \\
\text { cyanobacterium Spirulina } \\
\text { platensis, } 2010\end{array}$ & $\begin{array}{l}\text { Rutwik Ravindra Mandakini, } \\
\text { Thengodkar, S. Sivakami }\end{array}$ & $\begin{array}{l}\text { Mikroalga biru hijau dapat } \\
\text { mendegradasi } 80 \mathrm{ppm} \text { klorpirifos } \\
\text { menggunakan alkali fosfatase sebagai } \\
\text { sumber enzim. }\end{array}$ \\
\hline
\end{tabular}

\section{PENUTUP}

Dari hasil penelitian Chen et al., Akbar dan Sultan, serta Thegodkar dan Sivakami, dapat diketahui bahwa beberapa jenis mikroba fungi, bakteri, dan alga mampu menyisihkan klorpirifos mencapai 50-100 mg/l. Dengan demikian, dapat diambil kesimpulan bahwa bioremediasi menjadi alternatif yang tepat untuk menyisihkan klorpirifos di lingkungan karena memanfaatkan aktivitas enzimatis mikroba dengan melakukan degradasi pada klorpirifos dan dapat menjadikan klorpirifos sebagai sumber nutrisi bagi pertumbuhannya. Oleh karena itu, penelitian mengenai bioremediasi lingkungan tercemar klorpirifos dapat terus dieksplorasi dengan menggunakan mikroba dari jenis yang berbeda. 


\section{DAFTAR PUSTAKA}

Agustiyani, Dewi. 2011. Potensi Bakteri Denitrifikasi dalam Biodegradasi Carbaryl pada Kondisi Anaerobik. Jurnal Teknologi Lingkungan. 12 (3): 233-348.

DOI: http://dx.doi.org/10.29122/jtl.v12i3

Akbar, Shamsa, Sikander Sultan. 2016. Soil bacteria showing a potential of chlorpyrifos degradation and plant growth enhancement. Brazilian journal of microbiology. 47 (3): 563-570.

DOI: http://dx.doi.org/10.1016/j.bjm.2016.04.009

Chalim, Abdul. 2010. Pengaruh Aplikasi Rhizobium dan Cendawan Mikoriza Arbuskula (Cma) terhadap Pertumbuhan Semai Acasia crassicarpaa. A. cunn. Ex Benth. pada Medium Tanah Terdegradasi. Indonesian Jurnal of Urban and Environmental Technology. 5 (4): 139-144.

DOI: http://dx.doi.org/10.25105/urbanenvirotech.v5i4.685

Chen, Shaohua, Chenglan Liu, Chuyan Peng, et al. 2012. Biodegradation of Chlorpyrifos and Its Hydrolysis Product 3,5,6-Trichloro-2-Pyridinol by a New Fungal Strain Cladosporium cladosporioides Hu-01. PLoS ONE 7 (10): e47205.

DOI: http://doi.org/10.1371/journal.pone.0047205

Barman, D.N., Md. Azizul Haque, Shah Md. Asraful Islam, et al. 2014. Cloning and expression of ophB gene encoding organophosphorus hydrolase from endophytic Pseudomonas sp. BF1-3 degrades organophosphorus pesticide chlorpyrifos. Ecotoxicol Environ Saf. 108: $135-41$.

DOI: https://doi.org/10.1016/j.ecoenv.2014.06.023

Briceno G., M.S. Fuentes, G. Palma, et al. 2012. Chlorpyrifos biodegradation and 3,5,6trichloro-2-pyridinol production by actinobacteria isolated from soil. International Biodeterioration \& Biodegradation. 73: 1-7.

DOI: https://doi.org/10.1016/j.ibiod.2012.06.002

Das, Ratul K., Saurabh Jyoti Sarma, Satinder Kaur Brar. 2014. Nanoformulation of InsecticidesNovel Products. Journal of Biofertilizers \& Biopesticides. 5: 1.

DOI: https://doi.org/10.4172/2155-6202.1000e120

Fan, Shuanghua, Kang Li, Yanchun Yan, et al. 2017. A novel chlorpyrifos hydrolase CPD from Paracoccus sp. TRP: Molecular cloning, characterization and catalytic mechanism. Electronic Journal of Biotechnology. 31: 10-16.

DOI: https://doi.org/10.1016/j.ejbt.2017.10.009

Fang, Hua, Yunglong Yu, Xiaoqiang Chu, et al. 2009. Degradation of chlorpyrifos in laboratory soil and its impact on soil microbial functional diversity. Journal of Environmental Sciences. 21 (3): 380-386.

DOI: https://doi.org/10.1016/S1001-0742(08)62280-9

Hardiani, Henggar, Teddy Kardiansyah, Susi Sugesty. 2011. Bioremediasi Logam Timbal (Pb) Dalam Tanah Terkontaminasi Limbah Sludge Industri Kertas Proses Deinking. Jurnal Selulosa. 1 (1): 31-41.

DOI: http://dx.doi.org/10.25269/jsel.v1i01.18

Jabeen, Hina, Samina Iqbal, Samina Anwar. 2014. Biodegradation of chlorpyrifos and 3, 5, 6trichloro-2-pyridinol by a novel rhizobial strain Mesorhizobium sp. HN3. Water and Environment Journal. 29 (1): 151-160.

DOI: https://doi.org/10.1111/wej.12081

Lu, Peng, Qinfen Li, Hongming Liu, et al. 2013. Biodegradation of chlorpyrifos and 3,5,6trichloro-2-pyridinol by Cupriavidus sp. DT-1. Bioresource Technology. 127: 337-342. DOI: https://doi.org/10.1016/j.biortech.2012.09.116

Singh, D.P., J.I.S. Khattar, J. Nadda, et al. 2011. Chlorpyrifos degradation by the cyanobacterium Synechocystis sp. strain PUPCCC 64. Environ Sci Pollut Res. 18:13511359.

DOI: https://doi.org/10.1007/s11356-011-0472-x 
Thabit, Tamer M.A., Medhat A.H. El-Naggar. 2013. Malathion degradation by soil isolated bacteria and detection of degradation products by GC-MS. International Journal Of Environmental Sciences. 3 (5): 1467-1476.

DOI: https://doi.org/10.6088/ijes.2013030500017

Thengodkar, Rutwik R.M., S. Sivakami. 2010. Degradation of Chlorpyrifos by an alkaline phosphatase from the cyanobacterium Spirulina platensis. Biodegradation. 21 (4): 637644.

DOI: https://doi.org/10.1007/s10532-010-9331-6

Vidali, M. 2011. Bioremediation. An overview. Pure and Applied Chemistry. 73 (7): 1163-1172. DOI: https://doi.org/10.1351/pac200173071163

Vladimir P., Beskoski, Gojgic-Cvijovic G.D., Milic Jelena S., et al. 2011. Bioremediation of soil polluted with crude oil and its derivatives: microorganisms, degradation pathways, technologies. Hemijska industrija. 66 (2): 275-289.

DOI: https://doi.org/10.2298/HEMIND110824084B

Widyatmoko, H. 2011. Akurasi pH sebagai Parameter Tingkat Pencemaran Logam Berat dalam Tanah. Indonesian Jurnal of Urban and Environmental Technology. 5 (5): 173-178.

DOI: http://dx.doi.org/10.25105/urbanenvirotech.v5i5.689 